\title{
An Expedient Protocol to the Synthesis of Benzo(b)furans by Palladium Induced Heterocyclization of Corresponding 2-Allylphenols Containing Electron Rich and Electron Capturing Substituents in the Arene Ring
}

\author{
Kiran Rao, Ruchi Tyagi, Navjeet Kaur, and D. Kishore \\ Department of Chemistry, Banasthali University, Banasthali 304022, India \\ Correspondence should be addressed to Navjeet Kaur; nvjithaans@gmail.com \\ Received 5 August 2012; Revised 1 September 2012; Accepted 2 September 2012 \\ Academic Editor: Yves Grohens \\ Copyright (C) 2013 Kiran Rao et al. This is an open access article distributed under the Creative Commons Attribution License, \\ which permits unrestricted use, distribution, and reproduction in any medium, provided the original work is properly cited. \\ A facile and rapid accessibility to the libraries containing several mono, and disubstituted benzo(b)furan derivatives substituted \\ with a variety of electron rich and electron capturing groups on 2, 4, 5, 6, and 7 positions of its nucleus has been explored using the \\ $\mathrm{PdCl}_{2}\left(\mathrm{CH}_{3} \mathrm{CN}\right)_{2}$ catalyzed heterocyclization of the corresponding 2-allylphenols to afford $\mathbf{2}(\mathbf{a}-\mathbf{m})$ in good yield and high purity.
}

\section{Introduction}

The development of methods of general applicability empowered with the capacity to provide high yield of the target molecules is a crucial step in the synthesis of molecular libraries of potentially useful medicinal agents [1-3]. Ever since, Koch et al. [4] carried out a quantitative analysis of physiologically active natural product scaffolds and showed that ones with two or three rings were most often found in active natural products; the interest in the various facet of the chemistry of small molecules has expanded exponentially thereafter.

Natural products continue to be a very important source in the discovery of newer drugs and newer physiologically active materials [5]. On account of benzo(b)furan ring system featuring in a large number of naturally occurring biologically active scaffolds [6] and in potentially useful pharmaceutical formulations, this nucleus has been recognized as a "privileged structure" in the design and the development of molecular probes for biological evaluations. For example, a number of benzo(b)furan derivatives have been investigated for their application as estrogen receptor (ER) ligands [7], $\mathrm{H}_{3}$ receptor antagonists selective ligands for the dopamine $\mathrm{D}_{3}$ receptor [8], and metalloproteinase-13inhibitors

In addition, some 2-pyridinone derivatives of benzo(b)furans have been identified [9] to be potent and selective nonnucleoside inhibitors of HIV-1 reverse transcriptase [10]. Another derivative namely; 2-[4-(benzofuran-2yl)carbonyl]-piperazin-1-yl-3-propyl pyridine [11], has been demonstrated to be endowed with good anti-HIV activity. Their seemingly limitless structural features coupled with their novel biological applications [12] have provided enormous inspiration for the development of new reactions and new methodologies for their synthesis. Most of the approaches for the formation of furan ring from arene derivatives involved the dehydration of o-hydroxybenzyl ketones under acidic conditions [13], base mediated decarboxylation of o-acylphenoxyacetic acids or esters [14], cyclofragmentation of oxiranes [15] (available from the corresponding o-hydroxybenzophenones), dehydrative cyclization of phenoxyalkyl ketones [16], palladium(II) catalyzed cyclization of aryl acetylenes [17], o-alkenyl or o-alkynyl phenols [18, 19], or deprotection of benzyl ethers under basic conditions [20]. However, most of these methods require strong acidic or basic conditions, which make them less applicable to the 
substrates containing acid and base sensitive groups. Coupled with this, most often they require such materials which are not easily accessible. Consideration of these factors has led the heterocyclization of 2-allylphenols with organopalladium reagent to emerge as a most valid and acceptable alternative to other known methods, in providing a facile one pot synthesis of benzo(b)furan derivatives under mild conditions [18]. As 2-allylphenols can be prepared easily by the Claisen rearrangement of the corresponding allylphenyl ethers [21], the palladium induced heterocyclisation of these provides a method of general applicability to the benzo(b)furan synthesis. Though the scope and utility of this methodology has been demonstrated [18] earlier in synthesis but its versatility to the synthesis of benzo(b)furan derivatives containing a wide array of electron releasing and electron-withdrawing substituents in the arene ring has not been fully explored (see Scheme 1).

\section{Experimental}

All the melting points were determined in open glass capillaries and are uncorrected. The IR spectra were recorded on $\mathrm{KBr}$ disc using Perkin Elmer-1800 infrared. ${ }^{1} \mathrm{H}-\mathrm{NMR}$ spectra were recorded in $\mathrm{CDCl}_{3}\left(\mathrm{DMSO}-\mathrm{d}_{6}\right)$ on model AC300F (Brucker) spectrophotometer. The mass spectra were recorded on a Joel SX-102 (EI/CI/FAB) mass spectrometer at $70 \mathrm{eV}$. Microanalytical results were obtained from NCL Pune (India). The reactions were monitored by TLC on silica gel G plates and the spots were detected by exposing the plates to UV radiations at $254 \mathrm{~nm}$.

The 2-allylphenols [22] were prepared from the Claisen rearrangement of the corresponding allylphenyl ethers. Substituted phenols required in the synthesis were obtained from commercial sources.

\subsection{Preparation of Dichlorobis(acetonitrile)palladium(II)} Complex. Anhydrous palladium(II) chloride was suspended in dry acetonitrile and the resulting dark brown slurry was stirred for $12 \mathrm{~h}$ at $25^{\circ} \mathrm{C}$, which produced an orange slurry. Filteration followed by drying gave virtually a quantitative yield of the complex.

2.1.1. Stoichiometric Cyclization: General Procedure. Preparation of 5-Bromo-2-methyl Benzo(b)furan (2a). The $\mathrm{PdCl}_{2}\left(\mathrm{CH}_{3} \mathrm{CN}\right)_{2}(260 \mathrm{mg}, 1 \mathrm{mmol}, 1$ equiv. $)$ was placed in a $100 \mathrm{~mL}$ two necked flask fitted with a stopcock, stir bar, and serum cap. The flask was flushed with nitrogen and a constant pressure of nitrogen was maintained throughout the reaction. THF $(15 \mathrm{~mL})$ was added to the complex via syringe and allowed to stir for 5-10 min. 2-Allyl-4-bromophenol (1a) (213 mg, $1 \mathrm{mmol}, 1$ equiv.) was taken in THF $(5.0 \mathrm{~mL})$ and added to the slurry of complex via a syringe. The mixture was stirred for $1.5-2 \mathrm{~h}$. $\mathrm{Et}_{3} \mathrm{~N}(100 \mu \mathrm{L}$.) with syringe was added to this solution. After stirring for an additional $1.0 \mathrm{~h}$, a second equivalent of $100 \mu \mathrm{L}$. of $\mathrm{Et}_{3} \mathrm{~N}$ was added. Finally, a third equivalent of $100 \mu \mathrm{L}$. $\mathrm{Et}_{3} \mathrm{~N}$ was added after further $1 \mathrm{~h}$ stirring. The mixture was then allowed to stir for $2 \mathrm{~h}$ and then

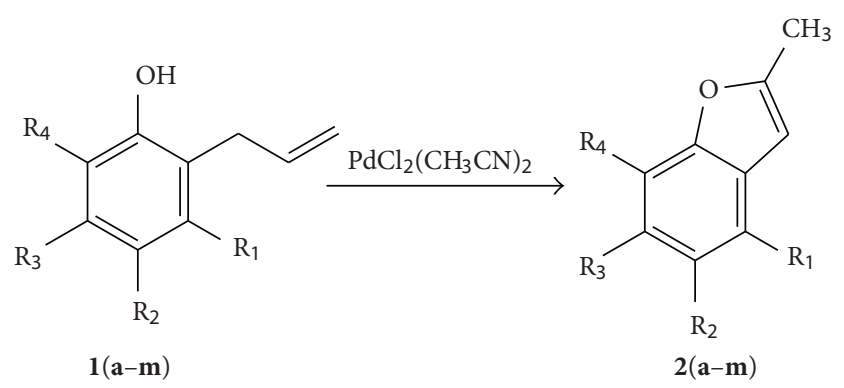

Scheme $1: \mathrm{R}_{1}, \mathrm{R}_{2}, \mathrm{R}_{3}$, and $\mathrm{R}_{4}=\mathrm{H}, \mathrm{Br}, \mathrm{Cl}, \mathrm{Me}, \mathrm{NO}_{2}, \mathrm{OMe}$, COOMe, COOEt, $\mathrm{CHO}$ represent arene ring substituents.

filtered. The resulting solution was concentrated on a rotatory evaporator. The product was purified by recrystallization with hexane to give 5-bromo-2-methylbenzo(b)furan (2a). Similarly other benzo(b)furans $\mathbf{2}(\mathbf{b}-\mathbf{m})$ were prepared.

2.1.2. Catalytic Cyclization. The yields of the substituted benzo(b)furans were found to be lower in case of stoichiometric cyclization and moreover, it required one mole equivalent (the stoichiometric amount) of fairly expensive palladium chloride reagent. Thus, the Pd induced cyclisation of 2-allyl phenols was carried out under catalytic conditions, which gave acceptable yields of the products.

Preparation of 5-Bromo-2-methyl Benzo(b)furan (2a). General procedure. In a $100 \mathrm{~mL}$ two necked flask fitted with a stopcock, serum cap and stir bar were placed $\mathrm{PdCl}_{2}\left(\mathrm{CH}_{3} \mathrm{CN}\right)_{2}(25 \mathrm{mg}$, $0.01 \mathrm{mmol}), \mathrm{p}$-benzoquinone $(108 \mathrm{mg}, 1 \mathrm{mmol})$, and $\mathrm{LiCl}$ (420 mg, $10 \mathrm{mmol}$ ). The flask was flushed with nitrogen and a constant pressure of nitrogen was maintained throughout the reaction. THF $(15 \mathrm{~mL})$ was then added and the mixture was stirred for 3-5 min. The 2-allyl-4-bromophenol, (1a) (213 mg, $1 \mathrm{mmol})$ in THF $(5.0 \mathrm{~mL})$ was added to the flask via a syringe and the solution was refluxed for $18 \mathrm{~h}$. The THF was removed on rotatory evaporator and the residue was taken up in ether $(25 \mathrm{~mL})$ and stirred for $20 \mathrm{~min}$ with a small amount of decolorizing carbon. The product was purified by recrystallization from hexane to give 5-bromo-2methyl benzofuran (2a). Similarly other benzofurans 2(b-m) were prepared. Reaction conditions $\mathbf{2}(\mathbf{a}-\mathbf{m})$ obtained under stoichiometric and catalytic conditions are summarized in Table 1.

5-Bromo-2-methyl Benzofuran (2a). Yield 76\%, m.p. $502^{\circ} \mathrm{C}$, IR $(\mathrm{KBr}) \mathrm{cm}^{-1}: 3015,2922,1625,1287,590 ;{ }^{1} \mathrm{H}$ NMR $(400 \mathrm{MHz}$, $\left.\mathrm{CDCl}_{3}\right) \delta$ ppm: $7.66[1 \mathrm{H}, \mathrm{s}], 7.36[1 \mathrm{H}, J=7.8 \mathrm{~Hz}, \mathrm{~d}], 7.31$ $[1 \mathrm{H}, J=7.7 \mathrm{~Hz}, \mathrm{~d}], 6.24[1 \mathrm{H}, \mathrm{s}], 2.16[3 \mathrm{H}, \mathrm{s}] ; \mathrm{MS}: \mathrm{m} / \mathrm{z}: 211$ $\left[\mathrm{M}^{+}\right]$, analysis: Calcd./found for $\mathrm{C}_{9} \mathrm{H}_{7} \mathrm{OBr}$ : C, 51.19/51.38; $\mathrm{H}$, 3.34/3.32.

7-Bromo-2-methyl Benzofuran (2b). Yield 74\%, b.p. $553^{\circ} \mathrm{C}$, IR $(\mathrm{KBr}) \mathrm{cm}^{-1}: 3010,2925,1637,1273,585 ;{ }^{1} \mathrm{H}$ NMR $(400 \mathrm{MHz}$, $\left.\mathrm{CDCl}_{3}\right) \delta$ ppm: $7.43[1 \mathrm{H}, J=8.0 \mathrm{~Hz}, \mathrm{~d}], 7.36[1 \mathrm{H}, J=$ $7.8 \mathrm{~Hz}, \mathrm{~d}], 7.02[1 \mathrm{H}, J=7.5 \mathrm{~Hz}, \mathrm{t}], 6.28[1 \mathrm{H}, \mathrm{s}], 2.14[3 \mathrm{H}, \mathrm{s}]$; MS: m/z: $211\left[\mathrm{M}^{+}\right]$, analysis: Calcd./found for $\mathrm{C}_{9} \mathrm{H}_{7} \mathrm{OBr}: \mathrm{C}$, 51.19/51.35; H, 3.34/3.32. 
TABLE 1: Reactions' conditions ${ }^{\mathrm{a}}$ used for the Pd(II) induced cyclisation of the 2-allylphenols to benzo(b) furans.

\begin{tabular}{lcc}
\hline & $\begin{array}{c}\text { Stoichiometric } \\
\text { cyclization }(\mathrm{A})\end{array}$ & $\begin{array}{c}\text { Catalytic } \\
\text { cyclization }(\mathrm{B})\end{array}$ \\
\hline $\mathrm{PdCl}_{2}\left(\mathrm{CH}_{3} \mathrm{CN}\right)$ & 1.0 equiv. & 0.1 equiv. \\
Triethylamine & 3.0 equiv. & - \\
Benzoquinone & - & 1.0 equiv. \\
Lithium chloride & - & 1.0 equiv. \\
Solvent & $\mathrm{THF}$ & THF \\
\hline
\end{tabular}

The reactions were run in THF at $0.05 \mathrm{M}$.

5-Chloro-2-methyl Benzofuran (2c). Yield 69\%, m.p. $473^{\circ} \mathrm{C}$, IR $(\mathrm{KBr}) \mathrm{cm}^{-1}: 3017,2920,1628,1281,738 ;{ }^{1} \mathrm{H} \mathrm{NMR}(400 \mathrm{MHz}$, $\left.\mathrm{CDCl}_{3}\right) \delta$ ppm: $7.50[1 \mathrm{H}, \mathrm{s}], 7.38[1 \mathrm{H}, J=7.9 \mathrm{~Hz}, \mathrm{~d}], 7.20$ $[1 \mathrm{H}, J=7.7 \mathrm{~Hz}, \mathrm{~d}], 6.21[1 \mathrm{H}, \mathrm{s}], 2.16[3 \mathrm{H}, \mathrm{s}] ; \mathrm{MS}: \mathrm{m} / \mathrm{z}: 166$ $\left[\mathrm{M}^{+}\right] ; 168\left[\mathrm{M}^{+}+2\right]$, analysis: Calcd./found for $\mathrm{C}_{9} \mathrm{H}_{7} \mathrm{OCl}$ : C, 64.80/64.59; H, 4.23/4.25.

2,5-Dimethyl Benzofuran (2d). Yield 71\%, m.p. $42^{\circ} \mathrm{C}$, IR (KBr) $\mathrm{cm}^{-1}: 3014,2918,1624,1284,2955 ;{ }^{1} \mathrm{H}$ NMR $(400 \mathrm{MHz}$, $\left.\mathrm{CDCl}_{3}\right) \delta$ ppm: $7.30[1 \mathrm{H}, J=7.7 \mathrm{~Hz}, \mathrm{~d}], 7.26[1 \mathrm{H}, \mathrm{s}], 6.72$ $[1 \mathrm{H}, J=7.6 \mathrm{~Hz}, \mathrm{~d}], 6.18[1 \mathrm{H}, \mathrm{s}], 2.32[3 \mathrm{H}, \mathrm{s}], 2.15[3 \mathrm{H}, \mathrm{s}]$; MS: m/z: $146\left[\mathrm{M}^{+}\right]$, analysis: Calcd./found for $\mathrm{C}_{10} \mathrm{H}_{10} \mathrm{O}: \mathrm{C}$, 82.15/82.31; H, 6.90/6.88.

2-Methyl-5-nitro Benzofuran (2e). Yield 58\%, m.p. $102^{\circ} \mathrm{C}$, IR (KBr) cm $\mathrm{cm}^{-1}: 3022,2915,1630,1280,1360 ;{ }^{1} \mathrm{H}$ NMR $\left(400 \mathrm{MHz}, \mathrm{CDCl}_{3}\right) \delta$ ppm: $8.42[1 \mathrm{H}, \mathrm{s}], 8.12[1 \mathrm{H}, J=8.4 \mathrm{~Hz}$, d], $7.68[1 \mathrm{H}, J=8.1 \mathrm{~Hz}, \mathrm{~d}], 6.17[1 \mathrm{H}, \mathrm{s}], 2.17[3 \mathrm{H}, \mathrm{s}]$; MS: m/z: $177\left[\mathrm{M}^{+}\right]$, analysis: Calcd./found for $\mathrm{C}_{9} \mathrm{H}_{7} \mathrm{O}_{3} \mathrm{~N}: \mathrm{C}$, 60.99/61.12; H, 3.98/4.00.

2,4-Dimethyl Benzofuran (2f). Yield 78\%, m.p. $102^{\circ} \mathrm{C}$, IR $(\mathrm{KBr}) \mathrm{cm}^{-1}: 3020,2936,1625,1274 ;{ }^{1} \mathrm{H}$ NMR $(400 \mathrm{MHz}$, $\left.\mathrm{CDCl}_{3}\right) \delta$ ppm: $7.23[1 \mathrm{H}, J=7.7 \mathrm{~Hz}, \mathrm{~d}], 7.09[1 \mathrm{H}, J=7.2 \mathrm{~Hz}$, t], $6.94[1 \mathrm{H}, J=7.6 \mathrm{~Hz}, \mathrm{~d}], 6.21[1 \mathrm{H}, \mathrm{s}], 2.31[3 \mathrm{H}, \mathrm{s}], 2.11[3 \mathrm{H}$, s]; MS: $\mathrm{m} / \mathrm{z}: 146\left[\mathrm{M}^{+}\right]$, analysis: Calcd./found for $\mathrm{C}_{10} \mathrm{H}_{10} \mathrm{O}: \mathrm{C}$, 82.15/82.31; H, 6.90/6.92.

2,7-Dimethyl Benzofuran (2g). Yield 74\%, m.p. $42^{\circ} \mathrm{C}$, IR (KBr) $\mathrm{cm}^{-1}$ : 3011, 2922, 1635, 1272, 2952; ${ }^{1} \mathrm{H}$ NMR $(400 \mathrm{MHz}$, $\left.\mathrm{CDCl}_{3}\right) \delta$ ppm: $7.29[1 \mathrm{H}, J=7.8 \mathrm{~Hz}, \mathrm{~d}], 7.04[1 \mathrm{H}, J=7.5 \mathrm{~Hz}$, t], $6.86[1 \mathrm{H}, J=7.6 \mathrm{~Hz}, \mathrm{~d}], 6.19[1 \mathrm{H}, \mathrm{s}], 2.29[3 \mathrm{H}, \mathrm{s}], 2.13[3 \mathrm{H}$, s]; MS: m/z: $146\left[\mathrm{M}^{+}\right]$, analysis: Calcd./found for $\mathrm{C}_{10} \mathrm{H}_{10} \mathrm{O}: \mathrm{C}$, 82.15/82.31; H, 6.90/6.87.

7-Methoxy-2-methyl Benzofuran (2h). Yield 73\%, m.p. $42^{\circ} \mathrm{C}$, IR $(\mathrm{KBr}) \mathrm{cm}^{-1}$ : 3017, 2922, 1631, 1265, 1271, ${ }^{1} \mathrm{H}$ NMR $\left(400 \mathrm{MHz}^{\mathrm{CDCl}} \mathrm{CD}_{3}\right) \delta$ ppm: $7.08[1 \mathrm{H}, J=7.8 \mathrm{~Hz}, \mathrm{~d}], 7.03[1 \mathrm{H}$, $J=7.3 \mathrm{~Hz}, \mathrm{t}], 6.71[1 \mathrm{H}, J=7.7 \mathrm{~Hz}, \mathrm{~d}], 6.14[1 \mathrm{H}, \mathrm{s}], 3.62[3 \mathrm{H}$, s], $2.11[3 \mathrm{H}, \mathrm{s}]$; MS: m/z: $162\left[\mathrm{M}^{+}\right]$, analysis: Calcd./found for $\mathrm{C}_{10} \mathrm{H}_{10} \mathrm{O}_{2}$ : C, 74.16/74.34; $\mathrm{H}, 6.21 / 6.23$.

Ethyl-2-methylbenzofuran-7-carboxylate (2i). Yield 74\%, m.p. $65^{\circ} \mathrm{C}$, IR (KBr) cm $\mathrm{cm}^{-1}: 3015,2930,1640,1270,1680,1168$, 1252, ${ }^{1} \mathrm{H}$ NMR $\left(400 \mathrm{MHz}, \mathrm{CDCl}_{3}\right) \delta \mathrm{ppm}: 7.90[1 \mathrm{H}, J=$ $8.2 \mathrm{~Hz}, \mathrm{~d}], 7.69[1 \mathrm{H}, J=8.0 \mathrm{~Hz}, \mathrm{~d}], 7.21[1 \mathrm{H}, J=7.4 \mathrm{~Hz}, \mathrm{t}], 6.21$ $[1 \mathrm{H}, \mathrm{s}], 4.25[2 \mathrm{H}, \mathrm{s}], 1.21[3 \mathrm{H}, \mathrm{s}], 2.16[3 \mathrm{H}, \mathrm{s}] ; \mathrm{MS}: \mathrm{m} / \mathrm{z}: 204$
$\left[\mathrm{M}^{+}\right]$, analysis: Calcd./found for $\mathrm{C}_{12} \mathrm{H}_{12} \mathrm{O}_{3}$ : C, 70.57/70.78; $\mathrm{H}, 5.92 / 5.94$.

Methyl-2-methylbenzofuran-7-carboxylate (2j). Yield 74\%, m.p. $107^{\circ} \mathrm{C}$, IR (KBr) cm $\mathrm{cm}^{-1}$ : 3020, 2918, 1629, 1261, 1685, 1168, 1252, ${ }^{1} \mathrm{H}$ NMR $\left(400 \mathrm{MHz} \mathrm{CDCl}_{3}\right) \delta \mathrm{ppm}: 7.86[1 \mathrm{H}$, $J=7.9 \mathrm{~Hz}, \mathrm{~d}], 7.65[1 \mathrm{H}, J=7.7 \mathrm{~Hz}, \mathrm{~d}], 7.24[1 \mathrm{H}, J=7.1 \mathrm{~Hz}, \mathrm{t}]$, $6.26[1 \mathrm{H}, \mathrm{s}], 3.71[3 \mathrm{H}, \mathrm{s}], 2.10[3 \mathrm{H}, \mathrm{s}]$; MS: m/z: 190, analysis: Calcd./found for $\mathrm{C}_{11} \mathrm{H}_{10} \mathrm{O}_{3}$ : C, 69.44/69.65; H, 5.30/5.32.

2-Methylbenzofuran-7-carbaldehyde (2k). Yield 72\%, m.p. $96^{\circ} \mathrm{C}$, IR (KBr) cm ${ }^{-1}: 3018,2920,1635,1263,1710 ;{ }^{1} \mathrm{H}$ NMR $\left(400 \mathrm{MHz}, \mathrm{CDCl}_{3}\right) \delta \mathrm{ppm}: 9.71[1 \mathrm{H}, \mathrm{s}], 7.71[1 \mathrm{H}, J=7.9 \mathrm{~Hz}$, d], $7.68[1 \mathrm{H}, J=7.8 \mathrm{~Hz}, \mathrm{~d}], 7.31[1 \mathrm{H}, J=7.2 \mathrm{~Hz}, \mathrm{t}], 6.21[1 \mathrm{H}$, s], $2.18[3 \mathrm{H}, \mathrm{s}]$; MS: m/z: $160\left[\mathrm{M}^{+}\right]$, analysis: Calcd./found for $\mathrm{C}_{10} \mathrm{H}_{8} \mathrm{O}_{2}$ : C, 74.97/74.73; $\mathrm{H}$, 5.26/5.24.

2,5,7-Trimethyl Benzofuran (2l). Yield 71\%, m.p. $190^{\circ} \mathrm{C}$, IR $(\mathrm{KBr}) \mathrm{cm}^{-1}: 3010,2915,1638,1270,2950 ;{ }^{1} \mathrm{H}$ NMR $\left(400 \mathrm{MHz} \mathrm{CDCl}_{3}\right) \delta \mathrm{ppm}: 7.09[1 \mathrm{H}, \mathrm{s}], 6.75[1 \mathrm{H}, \mathrm{s}], 6.24$ $[1 \mathrm{H}, \mathrm{s}], 2.26[3 \mathrm{H}, \mathrm{s}], 2.24[3 \mathrm{H}, \mathrm{s}], 2.15[3 \mathrm{H}, \mathrm{s}] ; \mathrm{MS}: \mathrm{m} / \mathrm{z}: 160$ $\left[\mathrm{M}^{+}\right]$, Analysis: Calcd./found for $\mathrm{C}_{11} \mathrm{H}_{12} \mathrm{O}: \mathrm{C}, 82.45 / 82.71 ; \mathrm{H}$, 7.55/7.57.

4,6-Dibromo-2-methyl Benzofuran (2m). Yield 66\%, m.p. $66^{\circ} \mathrm{C}$, IR (KBr) cm ${ }^{-1}: 3022,2925,1630,1265,5950 ;{ }^{1} \mathrm{H}$ NMR $\left(400 \mathrm{MHz}, \mathrm{CDCl}_{3}\right) \delta$ ppm: $7.51[1 \mathrm{H}, \mathrm{s}], 7.47[1 \mathrm{H}, \mathrm{s}], 6.24[1 \mathrm{H}$, s], $2.14[3 \mathrm{H}, \mathrm{s}] ; \mathrm{MS}: \mathrm{m} / \mathrm{z}: 289\left[\mathrm{M}^{+}\right]$, Analysis: Calcd./found for $\mathrm{C}_{9} \mathrm{H}_{6} \mathrm{OBr}_{2}$ : C, 77.25/77.44; $\mathrm{H}, 2.33 / 2.35$.

\section{Results and Discussion}

The applicability of the palladium induced cyclization procedure to the synthesis of benzo(b)furan derivatives from the corresponding 2-allylphenols has been examined in the present work via stoichiometric as well as catalytic cyclization routes. In the stoichiometric cyclization, 2-allylphenol is believed to interact with dichlorobis(benzonitrile)palladium(II) in presence of $\mathrm{Et}_{3} \mathrm{~N}$ to form the crude benzo(b)furan derivatives. It has been reported that the treatment of 2-allylphenol with $\mathrm{Pd}$ on charcoal at $500-800^{\circ} \mathrm{C}$ gives 2 -methylbenzofuran. Compared to this, the present method which used the palladium induced heterocyclization of 2-allylphenols provided a very convenient synthetic entry to 2-substituted benzo(b)furans. The mechanism of formation of 2-substituted benzo(b)furans from the corresponding 2-allylphenols is outlined in Scheme 2 which is believed to involve the intramolecular oxypalladation of the substrate to give an intermediate (from palladium(II)chloride) followed by $\beta$-elimination of $\mathrm{PdHCl}$ species (where the hydrogen from the C-2 carbon is eliminated along with palladium). This elimination results an exo-methylenebenzo(b)furan species, which eventually isomerizes to the thermodynamically stable 2-methylsubstituted benzo(b)furans. Although the stoichiometric cyclization provided a simple and convenient synthetic entry into the benzo(b)furan nucleus under mild conditions but it suffered from the requirement of one mole equivalent (the stoichiometric amount) of fairly expensive palladium chloride 


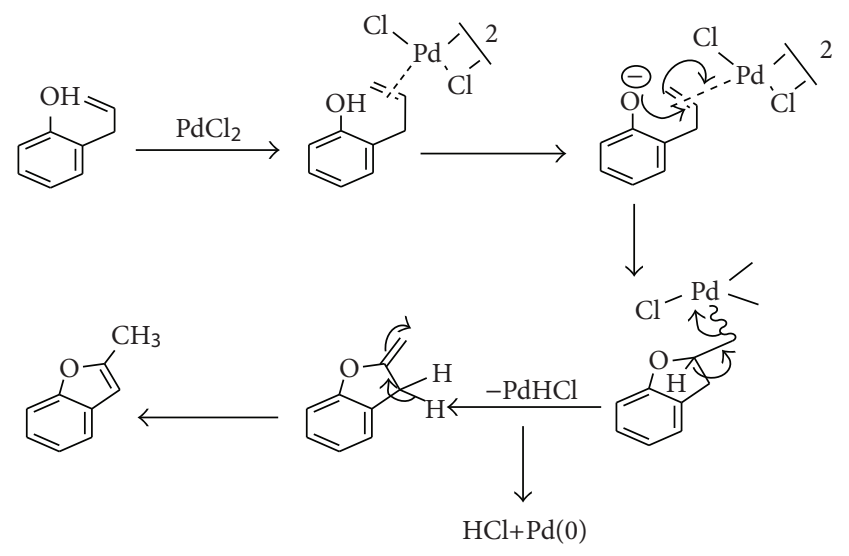

SCHEME 2: Mechanism of formation of 2-substituted benzofuran derivatives.

reagent. Though the palladium is not consumed in the reaction and is reduced to metallic palladium but recycling of it requires either tedious reoxidation or costly "trading in" of $\mathrm{PdCl}_{2}$ salt. For this reason, the application of catalytic cycle to carry out this process appeared to be less cumbersome, but it required to find a method to reoxidize $\mathrm{Pd}(0)$ to $\mathrm{Pd}(\mathrm{II})$ in the presence of 2-allylphenols and benzo(b)furans, both of which are readily oxidizable. In addition, the oxidizing agent should be such that it does not complex strongly to substrate or to $\operatorname{Pd}(\mathrm{II})$ species, if this happened, it would interfere with the cyclization process. Consideration of these factors prompted us to use p-benzoquinone as a suitable oxidizing agent in this process. The formation of compounds 2(a-m) were unequivocally established on the basis of their microanalysis, IR, ${ }^{1} \mathrm{HNMR}$, and MS spectral data, which were found to be in good agreement with the assigned structures. The IR spectrum of all the compounds on $\mathrm{KBr}$ pellet exhibited a sharp peak at $1287 \mathrm{~cm}^{-1}$ for the presence of $\mathrm{C}-\mathrm{O}-\mathrm{C}$ framework in the molecule. Along with this, disappearance of peak of phenolic $\mathrm{OH}$ group $\left(3595 \mathrm{~cm}^{-1}\right)$ clearly indicated the formation of benzo(b)furan ring in $\mathbf{2 a}$ from 1a. A sharp and strong intensity peak at $590 \mathrm{~cm}^{-1}$ suggested the presence of monosubstituted furan ring in the molecule which was further substantiated by the appearance of a singlet for $3 \mathrm{H}$ at $\delta 2.17$ in all the compounds $2(\mathbf{a}-\mathbf{m})$. This was attributed to the presence of $\mathrm{CH}_{3}$ group at 2-position in the molecule. The disappearance of singlet of one proton at $\delta 5.09$ for phenolic $\mathrm{OH}$ observed in its precursor 1a, clearly indicated the formation of benzo(b)furan 2a from 1a. Similar spectral interpretations established the structures of other compounds.

\section{Conclusion}

Our results corroborate strongly to the earlier reports on heteroannulation using organopalladium reagents. It established that palladium induced cyclization protocol provided a very convenient synthetic entry to the benzo(b)furans from 2-allylphenols substituted with electron releasing and electron capturing groups in the arene moiety. The results indicate that cyclization proceeds with high yield and purity in substrates containing electron-releasing groups. However, the electron-capturing group such as the nitro group formed product in low yield. This result was expected in view of the electrophilic character of the organopalladium reagent. Our study substantiates to the catalytic protocol to score better over stoichiometric process in heteroannulations using palladium reagents.

\section{References}

[1] J. J. Li and G. W. Gribble, Palladium in Heterocyclic Chemistry, 2007.

[2] L. S. Hegedus, "Palladium-catalyzed synthesis of heterocycles," Journal of Molecular Catalysis, vol. 19, no. 2, pp. 201-211, 1983.

[3] L. S. Hegedus, "Palladium(II)-assisted reactions of monoolefins," Tetrahedron, vol. 40, no. 13, pp. 2415-2434, 1984.

[4] M. A. Koch, A. Schufffenhauer, M. Scheck et al., "Charting biologically relevant chemical space: a structural classification of natural products (SCONP)," Proceedings of the National Academy of Sciences of the United States of America, vol. 102, no. 48, pp. 17272-17277, 2005.

[5] L. S. Hegedus, B. Lipshutz, H. Nozaki et al., Organometallics in Synthesis, Wiley \& Sons, 1996.

[6] S. I. Murahashi and T. Hosokowa, "New aspects of oxypalladation of alkenes," Accounts of Chemical Research, vol. 23, no. 2, pp. 49-54, 1990.

[7] A. Kasahara, T. Lzumi, and M. Ooshima, "Preparation of $N$ substituted phthalimides by the palladium-catalyzed carbonylation and coupling of o-dihalo aromatics and primary amines," The Journal of Organic Chemistry, vol. 56, no. 23, pp. 6573-6579, 1991.

[8] M. Yoshida, Y. Morishitaa, M. Fujitaa, and M. Ihara, "Facile syntheses of substituted 2,3-dihydrofurans and benzofurans by palladium-catalyzed reactions of propargylic carbonates with nucleophiles," Tetrahedron Letters, vol. 45, no. 9, pp. 1861-1864, 2004.

[9] M. Ionita, J. Roger, and H. Doucet, "Palladium catalyzed direct 3-arylation of benzofurans using low catalyst loadings," ChemSusChem, vol. 3, no. 3, pp. 367-376, 2010.

[10] A. Mustafa, Chemistry of Heterocyclic Compounds: Benzofurans, vol. 29, 2008.

[11] W. S. Saari, J. S. Wai, T. E. Fisher et al., "Synthesis and evaluation of 2-pyridinone derivatives as HIV-1-specific reverse transcriptase inhibitors. 2. Analogs of 3-aminopyridin-2(1H)-one," Journal of Medicinal Chemistry, vol. 35, no. 21, pp. 3792-3802, 1992.

[12] S. M. Rida, S. A. Hawash, H. T. Fahmy, A. A. Hazza, and M. M. Meligy, "Synthesis and in vitro evaluation of some novel benzofuran derivatives as potential anti-HIV-1, anticancer, and antimicrobial agents," rchives of Pharmacal Research, vol. 29, no. 1, pp. 16-25, 2006.

[13] K. Manna and Y. K. Agarwal, "Microwave assisted synthesis of new indophenazine 1,3,5-trisubstruted pyrazoline derivatives of benzofuran and their antimicrobial activity," Bioorganic \& Medicinal Chemistry Letters, vol. 19, no. 10, pp. 2688-2692, 2009.

[14] W. B. Albert and R. W. Leonard, "Coumarone," Organic Syntheses, vol. 5, p. 251, 1973. 
[15] K. D. B. Aruna, G. K. Prakash, M. N. Kumarasamy, B. P. Nandheswarappa, B. S. Sheringara, and K. M. Mahadevan, "Synthesis and antimicrobial investigation of some novel phenyl pyrazole, azetidinone and diazenyl ethanone derivatives of benzofurans," Indian Journal of Chemistry B, vol. 46, pp. 336-343, 2007.

[16] L. D. Luca, G. Nieddu, A. Porcheddu, and G. Giacomelli, "Some recent approaches to the synthesis of 2-substituted benzofurans," Current Medicinal Chemistry, vol. 16, no. 1, pp. 1-20, 2009.

[17] L. D. Luca, G. Giacomelli, and G. Nieddu, "Synthesis of substituted benzofurans via microwave-enhanced catch and release strategy," Journal of Combinatorial Chemistry, vol. 10, no. 4, pp. 517-520, 2008.

[18] Y. Liao, M. Reitman, Y. Zhang, R. Fathi, and Z. Yang, "Palladium(II)-mediated cascade carbonylative annulation of o-alkynyl-phenols on silyl linker-based macrobeads: a combinatorial synthesis of a 2,3-disubstituted benzo[b]furan library," Organic Letters, vol. 4, no. 15, pp. 2607-2609, 2002.

[19] A. I. Roshchin, S. M. Kel'chevski, and N. A. Bumagin, "Synthesis of benzofurans via $\mathrm{Pd}^{2+}$-catalyzed oxidative cyclization of 2allylphenols," Journal of Organometallic Chemistry, vol. 560, no. 1-2, pp. 163-167, 1998.

[20] R. Alvarez, C. Martinez, Y. Madich, J. G. Denis, J. M. Aurrecoechea, and A. R. D. Lera, "A general synthesis of alkenyl-substituted benzofurans, indoles, and isoquinolones by cascade palladium-catalyzed heterocyclization/oxidative heck coupling," Chemistry, vol. 16, no. 42, pp. 12746-12753, 2010.

[21] E. M. Sanford, C. C. Lis, and N. R. McPherson, "The preparation of allyl phenyl ether and 2-allylphenol using the williamson ether synthesis and claisen rearrangement," Journal of Chemical Education, vol. 86, no. 12, pp. 1422-1423, 2009.

[22] J. P. Ryan and P. R. O'Connor, "The claisen rearrangement of phenyl allyl ethers, labeled with carbon-14," Journal of the American Chemical Society, vol. 74, no. 23, pp. 5866-5869, 1952. 

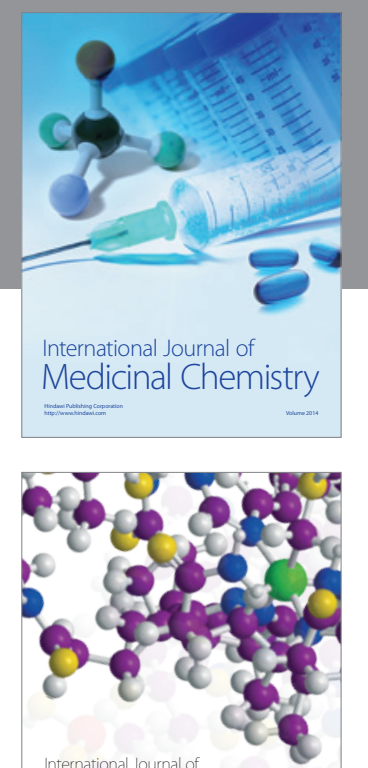

\section{Carbohydrate} Chemistry

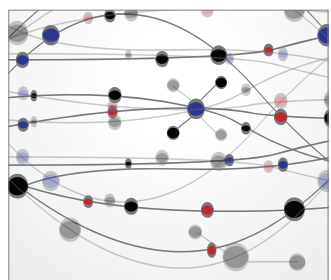

The Scientific World Journal
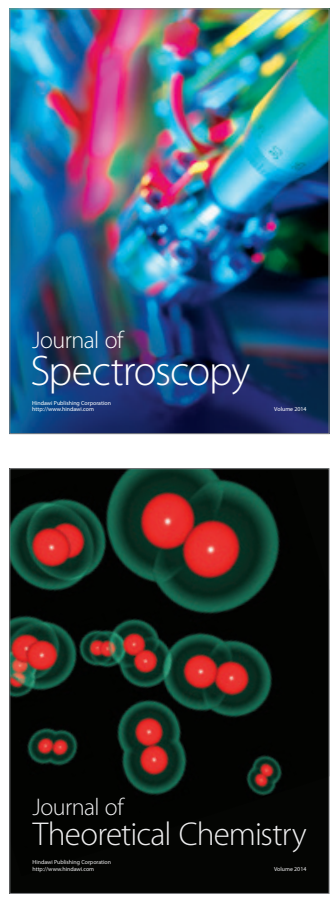
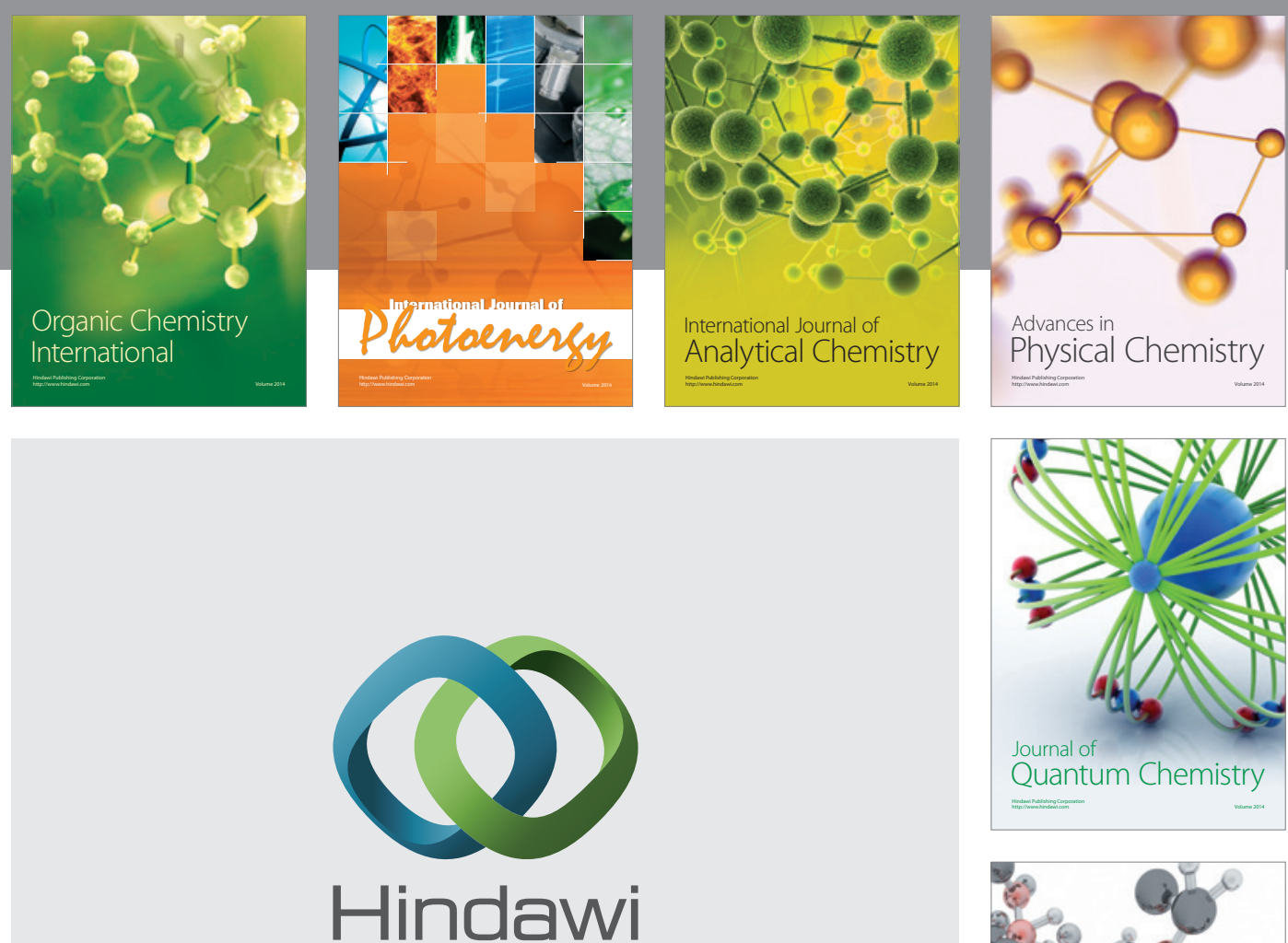

Submit your manuscripts at

http://www.hindawi.com

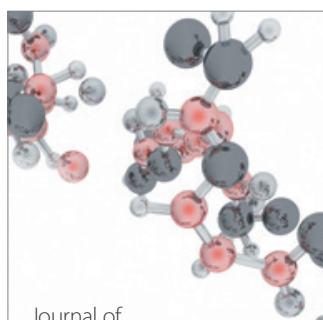

Analytical Methods

in Chemistry

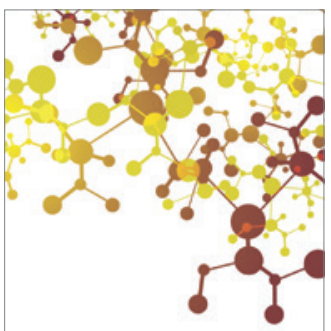

Journal of

Applied Chemistry

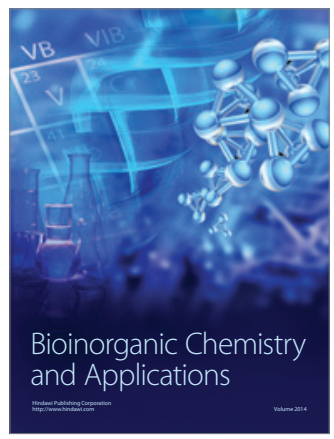

Inorganic Chemistry
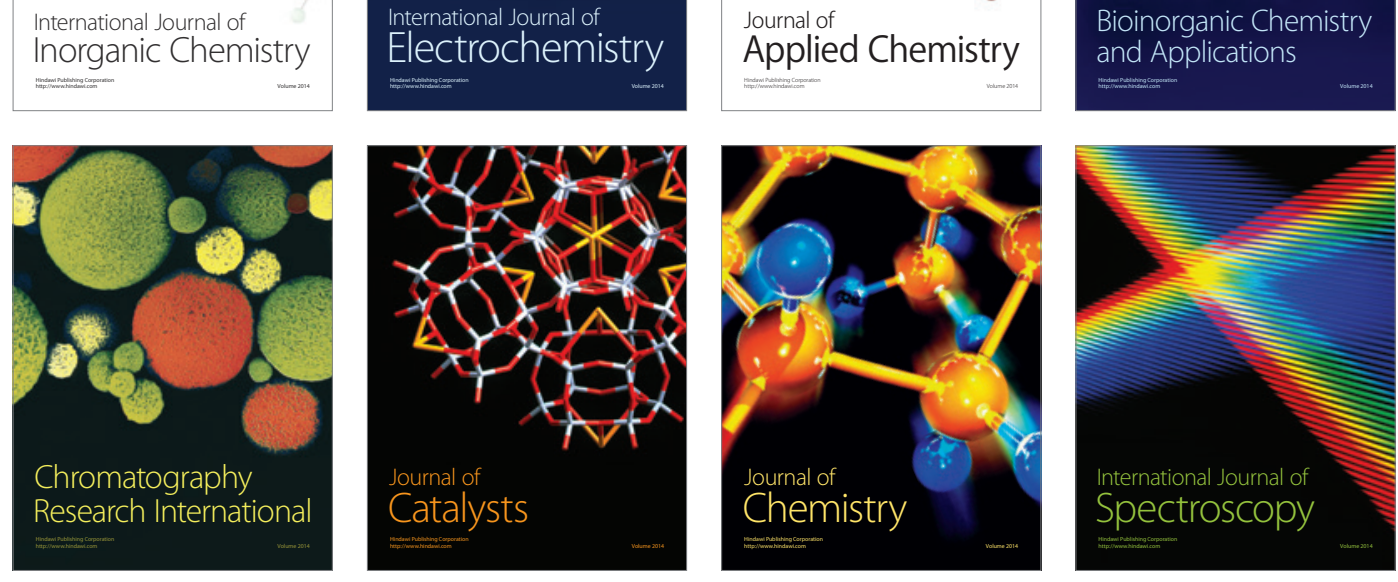